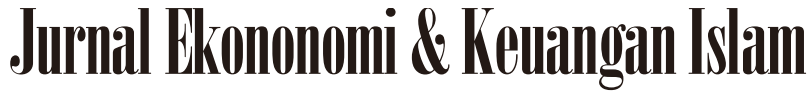

\author{
Available at http://journal.uii.ac.id/index.php/jeki
}

\section{Efisiensi perbankan Islam di Asia Tenggara}

Faaza Fakhrunnas

Peneliti di Islamic Economic Forum for Indonesia Development (ISEFID, Jakarta

e-mail: fakhrunnasfaaza@uii.ac.id

\section{Keywords:}

Efficency, total cost, total deposit, operating cost, total financing

DOI:

10.20885/JEKI.vol3.iss1.art4

\begin{abstract}
The development of Islamic banks in Southeast Asia increases quickly. To measure the Islamic banking performance, Islamic banking efficiency can be adopted as a benchmark. This study aims to measure the efficiency of Islamic banks in Southeast Asia. By applying Stochastic Frontier Analysis, this study utilizes input variable comprising total deposit and operating cost, then output variable consisting to total financing and earning asset whereas all variables mentioned-above are put as independent variable. Moreover, total cost is posited as dependent variable. By observing 28 Islamic banks in Southeast Asia during 2009-2012, this research finds that the level of efficiency Islamic Bank in Malaysia is 94,04\%, Brunei Darussalam is $88,59 \%$, and Indonesia is $88,35 \%$. By performing independent t-test, it shows that there has different efficiency between Islamic Bank in Indonesia and Malaysia, and also between Indonesia and Southeast Asia.
\end{abstract}

\begin{abstract}
Abstrak
Perkembangan perbankan Islam di Asia Tengara berkembang segan pesat. Untuk mengukur performa perbankan Islam, efisiensi perbankan Islam dapat digunakan sebagai acuan. Penelitian ini bertujuan untuk tingkat efisiensi di Asia Tenggara. Dengan mengaplikasikan Stochastic Frontier Analysis, penelitian ini menggunakan variabel input yang terdiri dari total deposit dan operational cost kemudian variabel output terdiri dari total financing dan earning asset dimana variabel-variabel tersebut ditempatkan sebagai variabel independen. Kemudian, total cost ditempatkan sebagai variabel dependen. Dengan melakukan observasi kepada 28 bank Islam di Asia Tenggara selama tahun 2009-2012, penelitian ini menemukan bahwa level efesiensi perbankan syariah di Malaysia mencapai 94,04\%, Brunei Darussalam $88,59 \%$, dan Indonesia mencapai $88,35 \%$. Dengan menggunakan independent t-test, penelitian tersebut menunjukan bahwa terdapat perbedaan efisiensi antara perbankan Islamdi Indonesia dan Malaysia, dan juga antara Indonesia dan Asia Tenggara.
\end{abstract}

\section{Pendahuluan}

Perkembangan perbankan Islam di Asia Tenggara dimulai pada tahun 1973 yang diawali dengan kelahiran $\mathrm{Al}$ Amanah Islamic Bank of Philipine. Disusul kemudian Bank Islam Malaysia Berhad pada tahun 1983 di Malaysia, Bank Muammalat di Indonesia pada tahun 1992, dan Tabung Amanah Islamic Brunei menjadi institusi finansial pertama yang lahir pada tahun 1991.

Hingga saat ini, perkembangan Perbankan Islam di Asia Tenggara telah berkembang cukup pesat. Di Malaysia, Perbankan Islam menguasai market share sebesar 18,9\% dengan total aset sebesar US\$ 106 milyar. Sementara jumlah perbankan Islam di Malaysia sampai tahun 2012 tercatat ada sebanyak 16 Perbankan Islam. Di Indonesia, terdapat 11 perbankan Islam yang tercatat pada tahun 2012 yang berhasil menguasai 4,2\% pangsa pasar perbankan dengan total aset sebesar US\$ 16 milyar. Sementara di Brunei Darusslam, dengan jumlah dua bank Islam, mampu menguasai pangsa pasar hingga 33,1\% dengan total aset sebesar US\$ 6,2 milyar. Menurut Public Life Project (2011), dengan jumlah penduduk muslim di Asia Tenggara sebesar 257,7 juta pada tahun 2010, menjadi peluang besar bagi Perbankan Islam untuk terus berkembang. Dengan potensi yang sangat besar diperlukan profesionalalitas dalam melakukan pengelolaan Perbankan Islam di Asia Tenggara.

Salah satu alat ukur kinerja Perbankan Islam adalah dengan melihat tingkat efisiensi industry tersebut. Efisiensi Perbankan Islam dapat dilakukan dengan menggunakan pendekatan Stochastic Frontier Approach (SFA). Penelitian serupa pernah dilakukan oleh Rahmawati dan Hosen (2012) yang meneliti efisiensi Perbankan Islam di Indonesia. Hasil penelitian tersebut menunjukan bahwa Perbankan Islam di Indonesia, yang diteliti pada tahun 1998-2010, ternyata belum memiliki efisiensi yang sempurna. Peneliti yang serupa juga dilakukan oleh Mokhtar et al (2006) yang melakukan penelitian mengenai efisiensi Perbankan Islam di Malaysia, dengan menggunakan lama tahun 1997-2003, menunjukan bahwa efisiensi Perbankan Islam di Malaysia belum memiliki 
efisiensi sebaik bank konvensional yang terdapat di Malaysia. Meskipun harus diakui, ada perbaikan efisiensi Perbankan Islam di Malaysia di setiap tahunnya.

Untuk itu, melihat perkembangan pesat Perbankan Islam di Asia Tenggara, perlu diketahui kinerja Perbankan Islam secara kekinian dalam kacamata efisiensi Perbankan Islam agar dapat dilihat sejauh mana profesionalitas Perbankan Islam dalam melaksanakan kinerjanya. Jika hal ini diketahui tentunya juga akan memberikan kemanfaatan kepada pihak-pihak yang memiliki kepentingan dengan Perbankan Islam di Asia Tenggara.

Ayub (2012) mengatakan bahwa sistem Perbankan Konvensional memilik perbedaan yang cukup mendasar dibandingkan dengan Perbankan Islam. Perbankan Islam tidak menggunakan instrumen bunga dalam melaksanakan transaksinya, dan digantikan dengan instrumen lain. Senada dengan hal tersebut, Ebrahem (2001) mendefinisikan Bank Islam sebagai bank yang memiliki keyakinan bahwa untuk tidak menggunakan bunga dalam kegiatan antara pembeli dan penjual ketika melakukan aktivitas ekonomi. Dimana dalam hal ini, perbankan Islam menggunakan syariah yang didasarkan kepada Al-Qur'an dan Al-Hadist dalam melakukan kegiatan transaksi yang dilakukan sehingga sesuai dengan prinsip-prinsip yang terdapat dalam agama Islam. Sedangkan Yudhistira (2004) mengatakan bahwa yang membedakan Perbankan Islam dan Perbankan Konvensional adalah dimana Perbankan Islam tidak menggunakan prinsip interest fee dan digantikan dengen profit and lost sharing (PLS) dalam melaksanakan fungsi bisnis dan melaksanakan fungsinya sebagai lembaga intermediasi.

Karim (2006) mengatakan bahwa produk yang ditawarkan dalam Perbankan Islam secara garis besar terbagi menjadi tiga bagian. Pertama, produk penyalur dana, kedua, produk penghimpun dana, ketiga produk jasa. Penyalur dana dalam hal ini meiputi $b a^{\prime} i$, ijarah, syirkah, dan akad pelengkap seperti hiwalah serta rahn. Untuk penghimpun dana meliputi wadi'ah, mudharabah. Sedangkan produk jasa Perbankan Islam meiputi sharf dan ijarah.

Berkaitan dengan efisiensi, Hadad et al (2003) mengatakan bahwa efisiensi adalah salah satu parameter kinerja yang secara konseptual merupakan salah satu kinerja yang menjadi dasar dari seluruh kinerja sebuah perusahaan. Kemampuan perusahaan untuk menghasilkan output yang maksimal dengan input yang ada merupakan ukuran kinerja yang diharapkan. Menurut Farrell (1957) mengatakan bahwa efisiensi sebuah perusahaan terdiri dari dua komponen. Pertama adalah technical efficiency yang menggambarkan kemampuan perusahaan untuk mencapai tingkat output yang maksimum dengan menggunakan tingkat input tertentu atau menghasilkan sejumlah output tertentu dengan menggunakan input seminimal mungkin. Secara lebih sederhana, technical efficiency mencerminkan kemampuan perusahaan dalam menghasikan output yang maksimal dengan menggunakan sejumlah input yang tersedia. Kedua adalah allocative efficiency yang menjelaskan kemampuan perusahaan dalam mengoptimalkan penggunaan inputnya dengan struktur harga dan teknologi tertentu.

Khan, et al (2013) melakukan penelitian mengenai efisiensi operasional Bank Islam di Pakistan dan Malaysia dengan cara mengevaluasi kinerja keuangan Bank Islam. Dalam penelitian tersebut menggunakan variabel Assets Utilizing Ratio (AU), Income to Expense Ratio (ITE), dan Operating Efficiency (OE). Dari hasil penelitian tersebut Bank Islam Pakistan lebih baik dalam menggunakan asetnya, sementara itu Bank Islam Malaysia dalam hal ITE mendapatkan hasil yang tinggi. OE yang dimiliki oleh Bank Islam Pakistan cenderung tinggi dan hal ini mengindikasikan bahwa biaya operasional berada diluar kontrol. Penelitian ini juga menyebutkan bahwa sebenarnya Bank Islam Pakistan menggunakan asset dengan sangat baik, namun dalam hal ini Bank Islam Malaysia lebih efisien karena dapat melakukan kontrol dalam biaya operasinya.

Ab-rahim, et al (2013) melakukan penelitian mengenai efisiensi kinerja Bank Islam Malaysia. Dalam penelitian tersebut, metodelogi yang digunakan adalah Data Envelopment Analysis (DEA), dimana input yang diambil adalah Personal Expense (PE), Fix Asset (FA), dan Total Deposits and Short Term Funding. Sedangkan output yang digunakan adalah Total Loan and Advances (LN), security portofolio (SEC), dan off-balance sheet items (OBS). Penelitian yang menggunakan data tahun 2006-2011 tersebut menyimpulkan bahwa secara rata-rata kontributor utama di Bank Islam lokal dan Bank Islam Asing di Malaysia sudah efisien secara alokatif. Selain itu, dalam penelitian tersebut juga menemukan bahwa Bank Islam asing lebih efisien dibandingkan dengan Bank Islam lokal terutama dalam hal technical efficiency dan allocative efficiency.

Rozzani dan Rahman (2013) melakukan penelitian mengenai penentuan efisiensi perbankan, dimana peneliti membandingkan efisiensi Perbankan Konvensional dan Perbankan Islam di Malaysia dengan menggunakan data tahun 2008-2011. Penelitian tersebut menggunakan sampel 19 Perbankan Konvensional dan 16 Bank Islam. Dalam penelitian tersebut, peneliti menggunakan alat ukur parametik, yakni Stochastic Frontier Analysis (SFA). Penelitian tersebut menggunakan tiga independen variabel, yakni bank size, operational cost, dan credit risk. Sedangkan untuk variabel dependen, peneliti menggunakan efficiency, dimana ownership menjadi variabel kontrol untuk membedakan kepemilikan asing dan kepemilikan lokal. Hasil penelitian tersebut, menunjukan bahwa dari perspektif profit efficiency menunjukan bahwa Bank Konvensional dan Bank Islam memiliki efisiensi yang hampir mirip. Namun, dalam hal ini, bank konvensional memiliki efesiensi yang lebih baik karena Bank Konvensional mempunyai peningkatan dari segi bank size yang lebih besar serta adanya 
penurunan biaya operasional dan resiko kredit yang semakin kecil. Sedangkan Bank Islam di Malaysia hanya belum sebaik Bank Konvensional namun masih belum maksimal dalam efisiensi dibidang biaya operasional.

Zainal dan Ismail (2013) melakukan penelitian mengenai efesiensi Perbankan Islam dengan menggunakan Data Envelopment Analysis (DEA). Peneliti menggunakan sampel Perbankan Islam di Malaysia dengan menggunakan data laporan keuangan pada tahun 2006-2010. Dalam penelitian tersebut, peneliti mencoba untuk mengukurtechnical efficiency (TE), pure technical efficiency (PTE), dan scale efficiency (SE) Bank Islam di Malaysia. Namun, dalam penelitian yang dilakukan oleh peneliti, jumlah Bank Islam yang diteliti tidak sama setiap tahunnya. Pada tahun 2008,2009, dan 2010 peneliti melakukan penelitian terhadap 15 bank. Pada tahun 2007, peneliti melakukan terhadap 11 bank, dan pada tahun 2006 hanya meneliti 10 bank. Sehingga, data yang didapatkan dalam perpektif panel data tidak balance. Dalam penelitian ini, peneliti menggunakan variabel input berupa total deposits (TOD), personal expenses (PE), dan fixed asset (FA). Sedangkan variable output, peneliti menggunakan variabel financial and advance (TOF) dan other earning assets (OEA). Dengan membedakan kepemilikan Perbankan Islam, yakni asing dan lokal, penelitian tersebut menunjukan bahwa efesiensi teknikal dan efesiensi skala pada semua Bank Islam di Malaysia pada tahun 2006-2010 kurang dari 100\%. Sumber utama ketidakefisienan tersebut terletak pada kesalahan skala produksi. Dalam hal ini, Bank Islam yang dimiliki oleh pemodal lokal memliki efisiensi teknikal dan efisiensi skala yang lebih baik dibangdingkan Bank Islam yang dimiliki oleh pemodal asing. Namun, dalam hal pure technical efficiency, Bank Islam yang dimiliki oleh Bank Asing lebih baik.

Ahmad dan Sufian (2011) melakukan penelitian mengenai efisiensi Perbankan Islam dimana dalam penelitian tersebut, peneliti mencoba menyajikan fakta-fakta disektor perbankan yang terdapat di negara-negara Asia. Dalam penelitian tersebut, peneliti menggunakan metodeData Envelopment Analysis (DEA) yang merupakan metode non parametik dalam mengukur efisiensi Perbankan Islam. Dalam hal ini, peneliti mengambil sampel dari beberapa Perbankan Islam yang terletak di Bangladesh, Indonesia, Malaysia, dan Pakistan. Sedangkan data laporan keuangan yang digunakan berada dalam periode 2001-2006. Dalam penelitian ini, peneliti menggunakan variabel output berupa total loans, income, dan investment. Sedangkan variebel inputnya berupa total dposits dan assets. Dari hasil penelitian tersebut menunjukan bahwa secara umum, Perbankan Islam di Asia tidak efisien dalam hal pure technical efficient dan scale efficient. Hal ini terjadi karena belum terkelola dengan baik dalam menggunakan sumber daya yang ada serta kontrol biaya operasional yang belum berjalan dengan baik. Dalam penelitian tersebut juga menunjukan bahwa Bank Islam di Indonesia lebih efisien dibandingkan dengan Bank Islam dinegara lain yang berada di wilayah Asia, diikuti oleh Pakistan, Bangladesh dan terakhir adalah Malaysia.

Rahman dan Rosman (2013) melakukan penelitian mengenai efisiensi Perbankan Islam, dengan membandingkan efisiensi perbankan Islam di Timur Tengah dan Afrika Utara dengan negara-negara Asia lainnya. Dalam penelitian ini, peneliti menggunakan Data Envelopment Analysis (DEA) sebagai alat analisa dengan menggunakan sampel sebanyak 63 Perbankan Islam. Peneliti juga menggunakan laporan keuangan Perbankan Islam dari tahun 2006-2009. Dalam penelitian itu, peneliti menggunakan perspektif intermdiation approach. Selain itu, peneliti juga menggunakan variabel input berupa satff costs,fixed assets dan total deposits. Sedangkan variabel output meliputi total loans dan earning assets. Dari hasil penelitian yang dilakukan peneliti menunjukan bahwa secara rata-rata, Bank Islam telah effisien dalam hal pure technical. Hal ini disebabkan mengindikasikan bahwa Bank Islam dapat mengontrol biaya secara efisien dan dapat menggunakan input yang ada untuk memproduksi output dengan tidak menghiraukan efek dari skala. Dalam konteks techincal efficiency, Bank Islam belum efisien. Hal ini dikarenakan Bank Islam mengoperasikan dengan skala yang salah dimana masih memerlukan pengurangan inputnya agar lebih efisien dalam hal mencapai skala yang optimum. Hal lain yang disimpulan dalam penelitian ini adalah bahwa efisiensi ternyata dipengaruhi oleh kondisi perekonomian negara. Perekonomian yang stabil menjadi keuntungan tersendiri bagi Bank Islam untuk menjadi lebih efisien. Sedangkan kapitalisasi menunjukan adanya pengaruh positif bagi efisiensi Perbankan Islam.

Rahmawati dan Hosen (2012) melakukan penelitian mengenai efisiensi manajemen pembiayaan Bank Islam di Indonesia. Dalam penelitian tersebut, peneliti menggunakan metode Stochastic Frontier Approach (SFA). Data yang digunakan oleh peneliti dalam adalah pada Bulan Januari 1998 dampai September 2010 dengan menggunakan sampel data seperti Bank Muammalat, Bank Syariah Mandiri, Bank Syariah Mega. Dalam penlitian ini, peneliti menggunakan variabel dependent berupa total cost, sedangkan variabel independent yang digunakan adalah personal expenses, cost-sharing expenses, total financing dan securities which owned. Dari hasil penelitian tersebut menunjukan bahwa tidak ada Bank Islam yang memiliki cost efficiency yang sempurna. Dimana Bank Muammalat hanya efisien sebesar 96,95\%, Bank Syariah Mandiri 96,92\%, dan Bank Mega Syariah sebesar $94,93 \%$.

Mokhtar et al (2006) melakukan penelitian mengenai efisiensi Perbankan Islam di Malaysia dengan menggunakan metode Stochastic Fronteir Approach (SFA). Penelitian tersebut menggunakan sampel perbankan Islam dan Islamic Windows di Malaysia dengan mengambil data antara tahun 1997-2003. Dalam penelitian yang 
dilakukan, peneliti menggunakan variebel independent yang menggambarkan output dan input perbankan. Yakni, input diwakili oleh total deposits dan total overhead, sedangkan output diwakili oleh earning asset. Untuk variabel dependent, peneliti menggunakan total asset. Dari penelitian tersebut menunjukan bahwa ratarata efisiensi untuk semua Perbankan Islam dan Islamic Windows di Malaysia mengalami tren pengingkatan dari periode ke periode meskipun saat peneliti melakukan penelitian, Bank Islam masih memiliki efisiensi yang lebih rendah dibandingkan dengan Bank Konvensional. Selain itu, hasil penelitian tersebut juga menunjukan bahwa Bank Islam di Malaysia memiliki efisiensi yang lebih baik dibandingkan dengan Islamic Windows dan Bank Islam di Malaysia yang dimiliki oleh investor asing ternyata memiliki efisiensi yang lebih baik dibandingkan dengan Bank Islam yang dimiliki oleh investor lokal.

Muhari dan Hosen (2013) melakukan penelitian mengenai efisiensi Bank Perkreditan Rakyat Syariah (BPRS) di Indonesia dengan menggunakan metode Stochastic Frontier Approach (SFA) dan menggunakan CAMEL ratio analysis. Dalam penelitian tersebut, peneliti melakukan penelitian terhadap 59 BPRS di Indonesia, dengan menggunakan data pada periode kuarter dua pada Bulan Juni 2011 sampai dengan kuarter empat sampai dengan Bulan Desember 2012. Dalam penelitian tersebut, variabel independen yang digunakan meliputi input dan output. Dalam input meliputi price of labour dan price of fund. Sedangkan output meliputi total financing dan placements with other banks. Sedangkan variabel enviromental factor menggunakan equity offer total assets dan non-performing financing. Dari penelitian tersebut disimpulkan bahwa rata-rata efisiensi BPRS di Indonesia sebesar $81,41 \%$. Sementara itu, pemilihan variabel indepeneden dan dependen yang digunakan dalam penelitian ini sangat relevan dan berkorelasi kuat sehingga dalam mengukur efisiensi yang ada, kekakuratan hasil bisa dipertanggungjawabkan.

Berdasarkan landasan teori dan penelitian yang telah dilakukan sebelumnya, maka peneliti mengajukan hipotesis bahwa ada perbedaan efisiensi Perbankan Islam di Asia Tenggara.

\section{Metode penelitian}

Populasi dalam penelitian ini adalah seluruh Perbankan Islam (tidak termasuk Bank Perkreditan Rakyat Syariah atau sejenisnya) yang berada di Asia Tenggara.Pengambilan sampel dalam penelitian ini dilakukan dengan metode purposive sampling, dengan kriteria, pertama, Perbankan Islam terdaftar sebagai sebagai Bank Islam dalam rentan waktu tahun 2009-2012. Kedua, Perbankan Islam digolongkan atau terdaftar sebagai Bank Umum. Ketiga, tersedia laporan keuangan dalam Bahasa Inggris atau Bahasa Melayu. Jadi berdasarkan kriteria tersebut, jumlah sampel yang memenuhi kriteria sebanyak dua puluh delapanPerbankan Islam yang terletak di Asia Tenggara dan tersebar di tiga negara, yakni Malaysia, Indonesia, dan Brunei Darussalam.

Variabel input dan output ditentukan berdasarkan penelitian-penelitian yang dilakukan oleh peneliti-peneliti sebelumnya. Input diartikan sebagai segala sesuatu yang menjadi pemasukan perusahaan dari sisi finansial. Sedangkan output diartikan sebagai bentuk penyaluran dana yang diberikan kepada pihak eksternal perusahaan untuk memberikan kemanfaatan bagi perusahan dan pihak terkait. Variabel input dalam hal ini adalah total deposit dan total overhead. Sedangkan variabel output dalam penelitian ini adalah earning asset dan total financing.

Analisis data penelitian ini menggunakan regresi berganda yang dilakukan untuk mengetahui pengaruh antara variabel independen terhadap variabel dependen. Persamaan regresinya adalah sebagai berikut;

$\operatorname{LogTC}_{i t}=\beta_{0}+\beta_{1} \operatorname{LogTD}_{i t}+\beta_{2}{\log O C_{i t}}_{1}+\beta_{3} \operatorname{LogTF}_{i t}+\beta_{4} \operatorname{LogEA} A_{i t}+\varepsilon_{i t}$

Dimana $\operatorname{LogTC}_{i t}$ merupakan bentuk logaritma linier dari total biaya (Total Cost). $\log T D_{i t}$ adalah logaritma dari jumlah deposit keseluruhan pada tahun pengamatan. $\log O C_{i t}$ adalah bentuk logaritma dari biaya oprasional (Operational Cost). $\log T F_{i t}$ adalah bentuk logaritma dari seluruh pembiayaan yang disalurkan oleh bank syariah. $\log E A_{i t}$ menunjukkan bentuk logaritma linier dari Earning Asset dan $\varepsilon_{i t}$ merupakan error term.

\section{Efisiensi Perbankan Islam}

Dalam melakukan penelitian, peneliti menggunakan pendekatan profit efficiency dengan menggunakan Stochastic Frontier Approach (SFA) sebagai metode untuk menganalisa data dengan menghitung deviasi dari fungsi profit yang sebelumnya diestimasikan terlebih dahulu dengan profit frontiernya. Berdasarkan penelitian yang dilakukan oleh para peneliti sebelumnya, ada beberapa alasan peneliti menggunakan pendekatan tersebut, karena pendekatan tersebut lebih baik dan lebih superior dibandingkan dengan pendekatan cost efficiency. Alasan-alasan tersebut antara lain, pertama, profit efficiency telah memperkirakan ineffeciency dari kedua sisi ouput maupun input. Sedangkan cost efficiency lebih banyak ditekankan pada sisi input, meskipun disisi lain, inefisiensi dari sisi output juga memiliki kemungkinan untuk terjadi.Kedua, dalam tataran konsep, pendekatan profit efficiency juga lebih diterima. Contohnya saja suatu bank harus mengeluarkan tambahan biaya sebesar Rp $\mathrm{X}$ dalam rangka meningkatkan keuntungan sebesar $\mathrm{Rp} \mathrm{Y}$ (dimana $\mathrm{Y}>\mathrm{X}$ ) dan variabel yang lainnya dianggap tetap, maka secara konsep ekonomi, profit efficiency lebih dapat diterima daripada cost efficiency. 
Ketiga, dalam hal ini cost efficiency didasarkan pada cost minimum pada suatu level output tertentu, padahal tingkat output tersebut belum tentu pada tingkat output optimal. Sehingga jika ada perubahan output maka kemungkinan hal ini juga akan mempengaruhi tingkat cost efficiency.Keempat, melihat kondisi pasar Perbankan Islam di Asia Tenggara, tidak dapat diklasifikasikan sebagai pasar persaingan sempurna tetapi cenderung pada pasar persaingan tidak sempurna.Aigner et al (1977) mengatakan bahwa profit suatu bank dalam Stochastic Frontier Analysis (SFA) dimodelkan untuk terdeviasi dari profit efficiency frontier-nya akibat adanya random noise dan inefisiensi.

Sementara itu, Berger dan Humprey (1997) mengatakan bahwa SFA adalah sebuah pendekatan ekonometrik yang menentukan bentuk fungsional untuk biaya, keuntungan, atau hubungan produksi diantara input, output, dan tentunya faktor lingkungan serta pendekatan ini memnungkinkan terdapat random error yang diasumsikan mengikuti distribusi standar simetrik. Suswandi (2007) menjelaskan lebih detail mengenai pengukuran efisiensi di bidang perbankan. Pertama, dalam konsep cost efficiency yang pada dasarnya mengukur tingkat biaya suatu bank dikomparasikan dengan bank lain yang memiliki biaya operasi terbaik dan menghasilkan output yang sama dengan teknologi yang sama. Kedua, adalah standard profit efficiency pada dasarnya mengukur tingkat efisiensi suatu bank yang didasarkan pada kemampuan bank dalam menghasilkan profit maksimal pada tingkat output tertentu dibandingkan dengan tingkat keuntungan yang diperoleh bank yang beroperasi terbaik dalam sampel. Ketiga, adalah alternative profit efficiency terjadi pada persaingan pasar yang tidak sempurna. Lebih khusus pada Stochastic Frontier Approach (SFA), metode ini menyatakan bahwa profit dari suatu bank dimodelkan untuk terdeviasi dari profit efficient frontier-nya akibat adanya random noise dan inefisiensi.

\section{Analisis Dan Pembahasan}

\section{Hasil Uji Regresi}

Dengan menggunakan SPSS 17.0, maka didapatkan hasil regresi sebagai berikut:

Tabel 1: Hasil Regresi Perbankan Islam di Asia Tenggara Tahun 2009-2012

\begin{tabular}{|c|c|c|c|c|c|}
\hline \multirow[t]{2}{*}{ Model } & \multicolumn{2}{|c|}{ Unstandardized Coefficient } & \multirow{2}{*}{$\begin{array}{l}\begin{array}{l}\text { Standardized } \\
\text { Coefficient }\end{array} \\
\text { Beta }\end{array}$} & \multirow[t]{2}{*}{$t$} & \multirow[t]{2}{*}{ Sig. } \\
\hline & $B$ & Std. Error & & & \\
\hline 1 (Constant) & -0.750 & 0.923 & & -0.812 & 0.418 \\
\hline Total_Deposit & 0.380 & 0.074 & 0.479 & 5.152 & 0.000 \\
\hline Operāting_Cost & 0.624 & 0.068 & 0.516 & 9.193 & 0.000 \\
\hline Total_Financing & -0.007 & 0.047 & -0.009 & -0.140 & 0.889 \\
\hline Earning_Asset & 0.007 & 0.038 & 0.010 & 0.189 & 0.851 \\
\hline
\end{tabular}

Hasil regresi tersebut diketahui bahwa, koefesien determinasi $\left(R^{2}\right)$ adalah 0,924 yang menunjukan bahwa variabel bebas secara bersama-sama mempengaruhi variabel tidak bebas sebesar 92,4\%. Sementara Uji F menunjukan bahwa nilai $\mathbf{F}_{\text {hitung }}$ sebesar 307.923 lebih besar dari $\mathbf{F}_{\text {tabel }}$ dengan N1 (k-1) = 4 dan N2 (N-K) $=100$ maka didapat $\mathbf{F}_{\text {tabel }}$ 2,92. Karena $\mathbf{F}_{\text {hitung }}$ lebih besar dari $\mathbf{F}_{\text {tabel }}$. Hal ini menunjukan bahwa secara simultan variabel independen berpengaruh signifikan terhadap variabel dependen pada taraf signifikansi sebesar 95\% $(\alpha=5 \%)$. Sementara pada uji t parsial, hanya total deposit dan operating cost yang berpengaruh signifikan positif terhadap variabel dependen.

\section{Hasil Uji Efisiensi Perbankan Islam}

Seteleh dilakukan uji efisiensi dengan menggunakan parameter Stochastic Frontier Approach (SFA), didaptkan hasil sebagai berikut:

Tabel 2: Efisiensi Perbankan Islam di Asia Tenggara

\begin{tabular}{lcccc}
\hline \multicolumn{1}{c}{ Negara } & 2009 & 2010 & 2011 & 2012 \\
\hline Indonesia & $88,96 \%$ & $87,56 \%$ & $88,01 \%$ & $88,90 \%$ \\
Malaysia & $92,97 \%$ & $93,58 \%$ & $94,46 \%$ & $95,15 \%$ \\
Brunei Darussalam & $88,09 \%$ & $90,14 \%$ & $87,67 \%$ & $88,47 \%$ \\
Efisiensi Rata-Rata & $90,00 \%$ & $90,42 \%$ & $90,05 \%$ & $90,84 \%$ \\
Efisiensi Maksimum & $92,97 \%$ & $93,58 \%$ & $94,46 \%$ & $95,15 \%$ \\
Efisiensi Minimum & $88,09 \%$ & $87,55 \%$ & $87,67 \%$ & $88,47 \%$ \\
\hline
\end{tabular}


Dari tabel tersebut menunjukan bahwa rata-rata efisiensi Perbankan Islam di Indonesia pada tahun 2009-2012 adalah sebesar 88,36\%, di Malaysia sebesar 94,04\%, dan di Brunei Darussalam sebesar 88,59\%.

\section{Hasil Uji Beda Independent Sample t-test}

Setelah melakukan Uji beda Independent Sample t-test, didapatkan hasil sebagai berikut:

Tabel 3:Perbandingan Efisiensi Perbankan Islam di Asia Tenggara

\begin{tabular}{|c|c|c|c|c|}
\hline \multirow{2}{*}{ Perbandingan } & \multicolumn{2}{|c|}{ Rata-Rata Efisiensi } & \multirow{2}{*}{ Nilai F } & \multirow{2}{*}{ Nilai $\mathbf{P}$} \\
\hline & Wilayah & Rata-Rata & & \\
\hline \multirow[t]{2}{*}{ Indonesia dan Malaysia } & Indonesia & $87,69 \%$ & 0,004 & 0,001 \\
\hline & Malaysia & $96,04 \%$ & & \\
\hline Indonesia dan & Indonesia & $87,69 \%$ & 0,007 & 0,001 \\
\hline Asia Tenggara & Asia Tenggara & $93,72 \%$ & & \\
\hline
\end{tabular}

Pada tabel tersebut dapat dilihat bahwa dilihat pada kolom F, signifikansinya menunjukan 0,004 yang artinya $<0,05$. Sedangkan dari kolom uji t menunjukan bahwa nilai $\mathrm{P}=0,001$ untuk uji 2 -sisi. Karena $\mathrm{P}$-value lebih kecil dibandingkan $\alpha=0,05$ maka, sehingga dapat disimpulkan bahwa secara statistik ada perbedaan efisiensi Perbankan Islam di Indonesia dan Malaysia. Dalam uji beda tersebut juga menunjukan bahwa Perbankan Islam di Indonesia dan Asia Tenggara memiliki varian yang berbeda. Hal ini ditunjukan dengan pada kolom $\mathrm{F}$, signifikansi mencapai 0,007 yang berarti $<0.05$. Sedangkan dari kolom uji t menunjukan bahwa nilai $\mathrm{P}$ $=0,001$ untuk uji 2-sisi. Karena P-value lebih kecil dibandingkan $\alpha=0,05$, sehingga dapat disimpulkan bahwa secara statistik ada perbedaan efisiensi Perbankan Islam di Indonesia dan Asia Tenggara. Hasil persamaan regresi tersebut akan digunakan dalam melakukan perhitungan efisiensi berdasarkan metode yang telah ditentukan sebelumnya.

\section{Pembahasan}

Secara rata-rata pertahun di tiap negara, efisiensi Perbankan Islam di Asia Tenggara mencapai 90,33\% dimana dalam segi pertumbuhan efisiensi setiap tahunnya, efisiensi Perbankan Islam tumbuh sebesar 0,3\%. Penurunan pertumbuhan efisiensi Perbankan Islam sempat dialami pada tahun 2011 karena terjadi penurunan efisiensi Perbankan Islam di Brunei Darussalam sebesar 2,46\% yang menyebabkan penurunan efisiensi Perbankan Islam di Asia Tenggara sebesar 0,4\%. Penurunan ini disebabkan karena pertumbuhan Perbankan Islam di Brunei Darussalam kalah pesat dibandingkan pertumbuhan Perbankan Islam di negara-negara lain di Asia Tenggara. Sementara itu, jika melihat perkembangan efisiensi Perbankan Islam di Asia Tenggara berdasarkan efisiensi per bank selama periode 2009-2012, maka akan didapati bahwa efisiensi tertinggi Perbankan Islam di Asia Tenggara dimiliki oleh Maybank Islamic Berhad di Malaysia yang mencapai rata-rata sebesar 99,25\% dan efisiensi terendah dimiliki oleh Bank BCA Syariah yang berada di Indonesia. Untuk rata-rata total efisiensi Perbankan Islam di Asia Tenggara adalah sebesar 91,67\%.

Perbedaan efisiensi yang dimiliki oleh masing-masing perbankan tentunya tidak bisa dilepaskan dari acuan atau indikator untuk mengukur efisiensi itu sendiri. Dengan menggunakan Stochastic Frontier Approach (SFA), maka indikator tersebut sangat bergantung Bank Islam yang menjadi acuan yang menjadi pembagi dalam mengukur efisiensi Perbankan Islam lainnya di Asia Tenggara. Dimana dalam hal ini, Bank Islam yang menjadi acuan adalah Bank Islam yang memiliki total cost optimal paling tinggi. Hal tersebut dicapai oleh Maybank Islamic Berhad di Malaysia pada tahun 2012 dengan efisiensi mencapai 100\%. Acuan efisiensi yang dipakai dalam penelitian ini adalah acuan per tahun efisiensi Perbankan Islam di Asia Tenggara pada tiap-tiap tahun tertentu. Tentunya, jika mengubah acuan tersebut, misalkan dengan menggunakan acuan rata-rata per tahun efisensi Perbankan Islam di Asia Tenggara, hasilnya pun dapat dipastikan berbeda.

Setelah melakukan analisa data, peneliti juga mengamati bahwa ternyata ukuran Bank Islam sangat berpengaruh terhadap efisiensi Perbankan Islam. Hal ini dapat dilihat pada data yang telah diolah dalam penelitian ini (dapat dilihat di lampiran).Dalam data tersebut menunjukan bahwa Perbankan Islam di Malaysia memiliki efisiensi di atas rata-rata efisiensi Perbankan Islam di Asia tenggara. Dari 16 Bank umum Islam di Malaysia, hanya satu, yakni Asian Finance Bank Berhad yang memiliki efisiensi dibawah rata-rata efisiensi Perbankan Islam di Asia Tenggara, sementara 15 lainnya memiliki efisiensi diatas rata-rata. Di Indonesia, hanya ada tiga Bank Islam yang memiliki efisiensi rata-rata, yakni Bank Mega Syariah, Bank BRI Syariah, dan Bank Syariah Mandiri. Sedangkan delapan Bank Islam yang lain memiliki efisiensi dibawah rata-rata. Di Brunei 
Darussalam, tidak ada Bank Islam yang memiliki efisiensi diatas rata-rata efisiensi Perbankan Islam di Asia Tenggara.

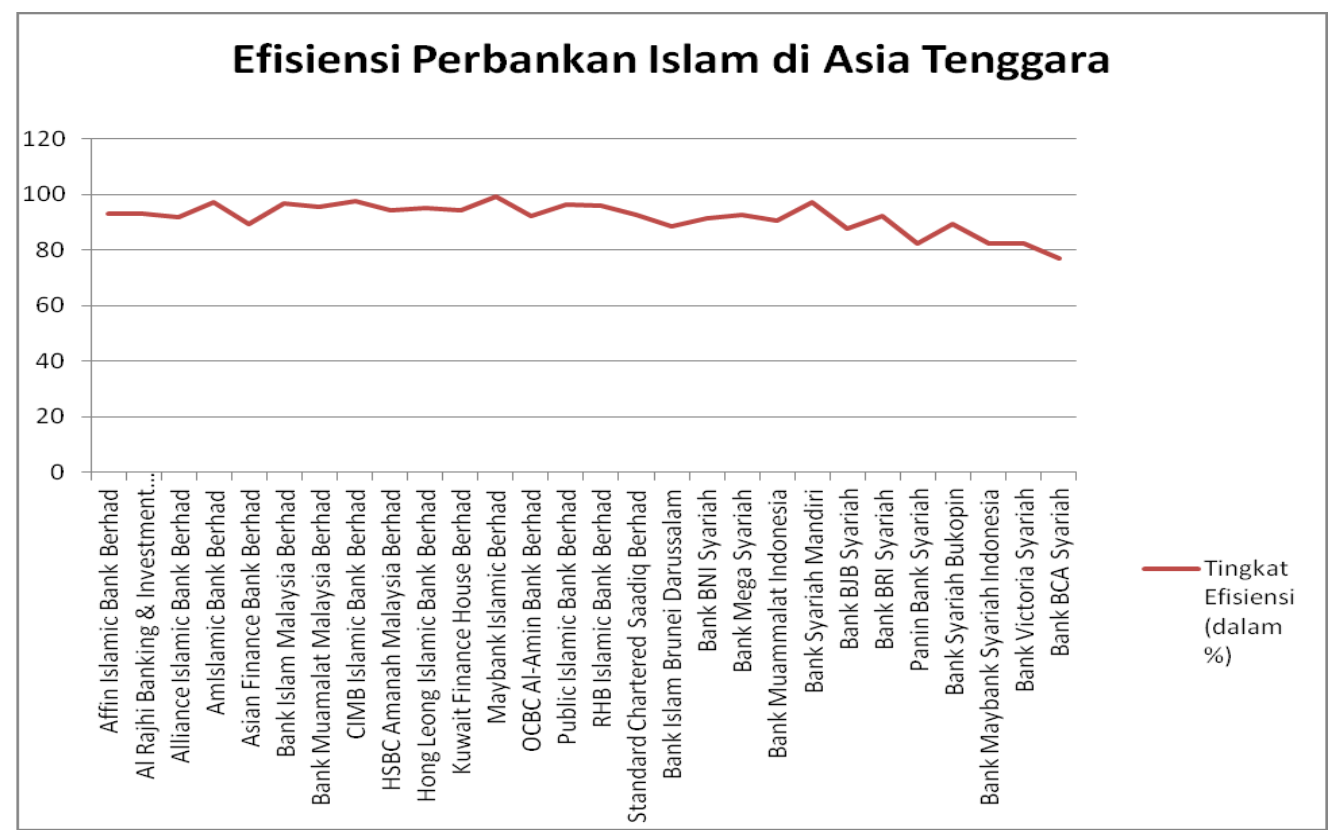

Grafik 4.1. Efisiensi Perbankan Islam di Asia TenggaraPeriode 2009-2012

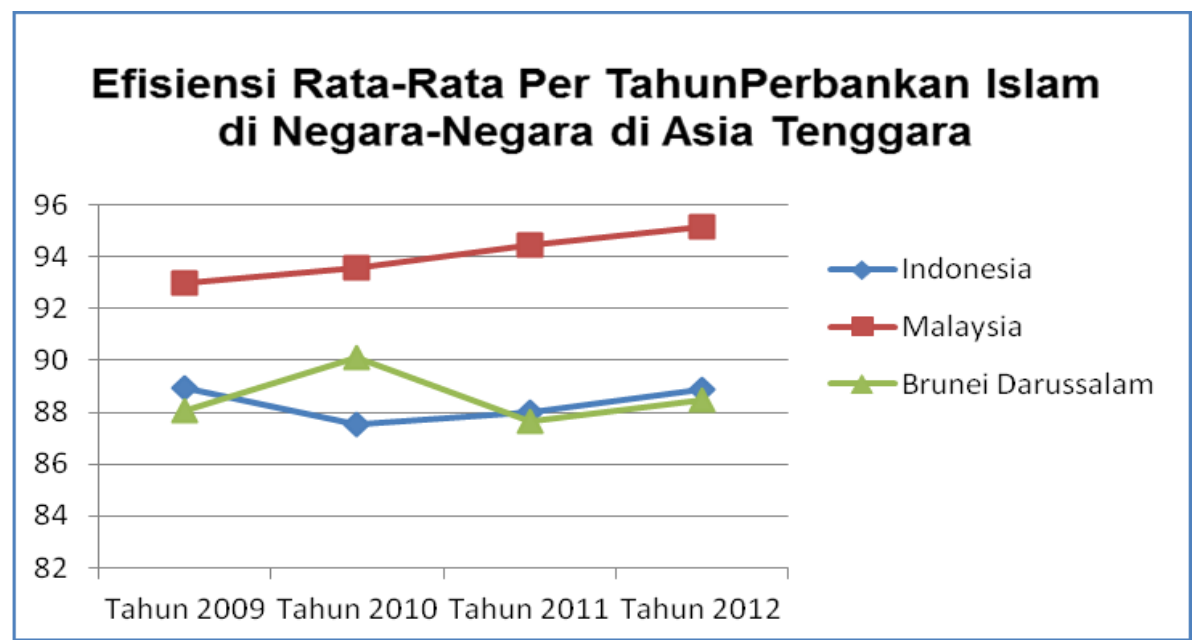

Grafik 4.2. Perbandingan Efisiensi Tiap Negara di Asia TenggaraPeriode 2009-2012

Perbedaan efisiensi Perbankan Islam di Asia Tenggara tidak hanya terjadi perbedaan per bank Islam, namun juga terjadi perbedaan efisiensi antar negara. Hal ini dapat dilihat pada grafik diatas yang menunjukan hal tersebut. Grafik tersebut juga menunjukan bahwa efisiensi Perbankan Islam di Malaysia menunjukan tingkat efisiensi yang tertinggi secara rata-rata tiap tahun jika dibandingkan dengan efisiensi Perbankan Islam di Indonesia dan Brunei Darussalam. Hal ini tidak bisa dilepaskan dengan adanya proporsionalitas antara input dan output yang dimiliki oleh Perbankan Islam di Malaysia. Selain itu, faktor lain juga menunjukan bahwa tingginya efisiensi Perbankan Islam di Malaysia juga tidak bisa dilepaskan dari faktor ekternal, dimana Perbankan Islam di Malaysia sudah lebih mapan dan berdiri lebih lama dibandingkan dengan negara lain di Asia Tenggara serta mendapat dukungan oleh pemerintah negara karena dilandasi oleh goverment driven.

Di Indonesia, efisiensi Perbankan Islam tidak sebaik di Malaysia. Hal ini dikarenakan masih ada enam Bank Islam yang masih berkembang dan belum mapan. Lebih mendetail, yang dimaksud dengan masih 
berkembang dan belum mapan adalah bahwa Bank Islam masih baru berdiri pada tahun 2010. Sehingga tingkat efisieni Bank Islam di Indonesia belum stabil. Semantara di Brunei Darussalam, tingkat efisiensi Perbankan Islam juga terlihat fluktuatif, hal ini dimungkinakan karena pertumbuhan Perbankan Islam di Brunei Darussalam yang lebih kecil dibanginkan dengan Perbankan Islam di Asia Tenggara. Hal ini bisa terlihat dari penurunan total cost yang mencapai 15\% dan menyebabkan penurunan efisiensi sebesar $6,7 \%$.

Perbedaan tingkat efisiensi Perbankan Islam di tiap-tiap negara di Asia Tenggara juga dapat dilihat dengan menggunakan uji beda independent sample t-test, dimana dalam uji tersebut menujukan bahwa terjadi perbedaan varian antara efisiensi Perbankan Islam di Indonesia dan Malaysia, hal ini juga dialami jika membandingkan efisiensi Perbankan Islam di Indonesia dan Asia Tenggara. Sehingga sekali lagi dapat disimpulkan bahwa terjadi perbedaan tingkat efisiensi Perbankan Islam di Asia Tenggara. Hal ini juga menandakan bahwa hipotesis yang disampaikan oleh peneliti menunjukan hal yang sama dengan hasil penelitian ini.

Dalam konteks varibel dependen, dalam analisa data yang telah dilakukan menunjukan bahwa ada dua variabel yang memiliki pengaruh signifikan positif, yakni operational cost dan total deposit. Jika lebih melihat hasil analisa data, variabel total deposit ini berpengaruh positif terhadap total cost sebesar 0,380. Hal ini berarti, apabila total deposit bertambah sebanyak 100\% maka total cost Perbankan Islam di Asia Tenggara akan bertambah sebanyak $38 \%$, begitu pula sebaliknya. Untuk variabel operational cost memiliki pengaruh signifikan positif terhadap total cost adalah sebesar 0,624. Hal ini berarti, apabila operational cost bertambah sebesar $100 \%$, maka total cost Perbankan Islam di Asia Tengara akan bertambah sebesar 62,4\%.

\section{Kesimpulan}

Penelitian ini menyimpulkan bahwa pertama, variabel independen yang digunakan dalam peneletian ini secara simultan berpengaruh signifikan terhadap total cost. Selain itu, pengaruh variabel yang digunakan dalam penelitian ini memiliki pengaruh sebesar 92,4\%. Sedangkan 7,6\% lainnya dipengaruhi oleh variabel lain yang tidak dimasukan dalam model pada penelitian ini. Kedua, telah diketahui bahwa dalam penelitian ini ada dua variebel yang berpengaruh signifikan positif dan terdapat dua variabel yang tidak berpengaruh signifikan. Variabel yang memiliki pengaruh yang signifikan adalah total deposit dan operational cost. Ketiga, didapati bahwa rata-rata total efisiensi Perbankan Islam di Asia Tenggara adalah sebesar 91,67\%. Dimana dalam hal ini ada 15 Bank Islam di Malaysia dan tiga Bank Islam di Indonesia memiliki efisiensi diatas rata-rata total efisiensi Perbankan Islam di Asia Tenggara. Efsiensi tertinggi Bank Islam dimiliki oleh Maybank Islamic Berhard yang mencapai 99,25\% dan BCA Syariah memiliki efisiensi terendah sebesar 76,92\%. Keempat, efisiensi Perbankan Islam di Asia Tenggara rata-rata per tahun sebesar 90,33\%. Dalam hal ini, Malaysia memiliki efsiensi tertinggi sebesar 94,04\%. Disusul Brunei Darussalam sebesar 88,59\% dan Indonesia sebesar 88,35\%. Dari data tersebut juga menunjukan adanya perbedaan tingkat efisiensi Perbankan Islam di setiap negara di Asia Tenggara.

Ada beberapa hal yang dapat menjadi masukan kepada kepada stakeholder Perbankan Islam di Asia Tenggara yang diharapkan memberikan kontribusi antara lain pertama, total deposit hendaknya dapat dimanfaatkan untuk melakukan pendanaan kepada nasabah Perbankan Islam di Asia Tenggara sehingga peran Perbankan Islam dapat lebih signifikan dalam menjalankan fungsinya sebagai lembaga intermediasi. Kedua, operational cost sebaiknya dapat lebih menjadi perhatian Perbankan Islam di Asia Tenggara, karena hal ini akan sangat berpengaruh terhadap efisiensi Perbankan Islam. Selain itu lebih khusus kepada industri Perbankan Islam di Indonesia yang sedang berkembang, sudah selayaknya memperhatikan lebih seksama dalam melakukan investasi di daerah-daerah dengan membuka kantor cabang atau pengembangan skala Perbankan Islam agar tidak ada pemborosan biaya, sehingga Perbankan Islam di Indonesia dapat lebih efisien.

\section{Daftar Pustaka}

Ab-rahim, R, Kadri, N, \& Islamil, F. (2013). Efficiency Performence of Malaysian Islamic Bank.Munich Personal RePEc Archive. Paper No. 46238; 1-10

Ahmad, N.H\&Noor, M. (2011). The Determinants Efficiency and Profitability of World Islamic Banks. IPEDR. (3): $228-223$

Aigner, D, Lovell, C.A.K, \& Schmidt, P. (1977). Formulation And Estimation of Stochatic Frontier Production Function Models. Journal of Economics, 6 (1): 21-37

Ayub, M. (2012). Understanding Islamic Finance. Jakarta. Gramedia Pustaka Utama

Berger, A. N \& Humprey, D.B. (1997). Efficiency of Financial Institution: International Survey and Direction for Future Research. TheWharton Financial Institution Center. 1-51. 
Ebrahem, M. S \&Joo, T. K. (2001). Islamic Banking in Brunei Darussalam. Internastional Journal of Social Economics. 28(4): 314-337

Farrell, M.J. (1957). The Measurement of Productive Efficiency. Journal of The Royal Statistical Society. 120(3): 253-290

Hadad, M. D, Santoso, W, Mardanugraha, E, \& Illyas, D. (2003). Pendekatan Parametrik untuk Efisiensi Perbankan Indonesia. Diperoleh pada 8 Oktober 2013 di http//.www.bi.go.id

Karim, A.A. (2006). Bank Islam. Jakarta: Rajawali Pers

Khan, M. A, Choudary, G. M, Asad, M, Khan, M.A, \& Naqvi, S. M. H. (2013). Operational Efficiency of Islamic Bank: The Case of Malaysia and Pakistan. Interdiciplinary Journal of Contempory Research in Business, 5(3); 660-668

Mokhtar, H. S. A. Abdullah, N, Al-Habshi, S. M. (2006). Effeciency of Islamic Banking in Malaysia: A Stochastic Frontier Approach. Journal of Economic Cooperation2: 37-70

Muhari, S., \& Hosen, M. N. (2013). Eficiency of The Sharia Rural Bank in Indonesia Lead to Modified Camel. International Journal of Academic Research in Economics and Management Science. 2 (5): 34-53

Ahmad, N.H\&Noor, M. (2011). The Determinants Efficiency and Profitability of World Islamic Banks. IPEDR. (3): $228-223$

Rahmawati, R \& Hosen, M. N. (2012). Efficency of Fund Management of Sharia Banking in Indonesia. International Journal of Academic Research in Economic and Management Sciences. 1(2): 144-157

Rahman, A.R.A, \&Rosman, R(2013). Efficiency of Islamic Banks: A Comparative Analysis of MENA and Asian Countries. Jurnal of Economic Cooperation and Development. 1 (34):53-92

Rozzani, N\&Rahman, A. (2013). Determinants of Bank Efficiency: Conventional versus Islamic. International Journal of Bussines and Management. 8 (14): 98-109

Suswandi. (2007). Analisa Efisiensi Perbankan Syariah di Indonesia. Skripsi Sarjana Strata I. Universitas Islam Indonesia, Yogyakarta

Yudhistira, D. (2004). Efficiency In Islamic Banking An Empirical Analysis of Eighteen Bank. Islamic Economic Studies. 12 (1): 1-19

Zainal, N. S. \&Ismail, M. (2012). Islamic Banking Efficiency: a DEA Approach. 3rd International Conference on Business and Economic Research Proceeding. Bandung Indonesia 